\title{
Physiochemical Analysis of Local (Fulani) Yoghurt Syrup Sold in Bauchi Metropolis
}

\author{
Shibdawa, M.A. ${ }^{1}$, Ushie, $\mathrm{O} \mathrm{A}^{2 *}$, Ogah E. ${ }^{2}$, Longbap B.D ${ }^{2}$ \\ ${ }^{I}$ Chemistry Department, AbubakarTafawaBalewa University Bauchi, Nigeria \\ ${ }^{2}$ Department of Chemical Science, Federal University, Wukari Nigeria
}

*Corresponding Author: Ushie, $\boldsymbol{O}$ A, Department of Chemical Science, Federal University, Wukari Nigeria. Email: afiushie@yahoo.com

\begin{abstract}
The study examined the quality of some yoghurt processed and sold in Bauchi Metropolis. Proximate analysis was carried out on three commercially available brands of yoghurt sample (\% Moisture; $84.2 \pm 0.2,83.2 \pm 0.2,70.5 \pm 0.3)$, (\% ash; $0.63 \pm 0.00,1.94 \pm 0.00,0.56 \pm 0.00)$, (\% total solids; $15.7,16.8$ ,29.4), (\% fat; $0.38 \pm 0.05,5 \pm 0.05,20 \pm 0.03),(p H ; 4.6,4.5,4.3)$, (mineral component: Ca:0.036, 0.016, 0.038, Mg; 1.505, 1.75, 1.52), (protein; 42.35, 40.6, 41.6), (carbohydrate; 8.41, 6.48, 5.66), (non-fat solid; 0. 7, 5.6, 9.4) and (microbiological; $4 \times 10^{-5} \pm 0.3,376 \times 10^{-} \pm 0.01$ ). The $\mathrm{pH}$ value of the samples ranged between 4.3-4.6 which were within the range for yoghurt marketed in the areas. There was marked variation in fat content of the product. The moisture content were within the range. Microbiological analysis indicated that Abdul yoghurt sample had the highest bacterial count. Yoghurt manufacturers need to improve on physiochemical analysis for better consumer acceptability
\end{abstract}

Keywords: Yoghourt, fura, nono, moisture content, ash content

\section{INTRODUCTION}

Yogurt is a fermented milk product consumed by large segments of our population either as a part of diet or as a refreshing beverage. It is a nutritiously balanced food containing almost all the nutrients present in milk but in a more assimilable form. It is obtained by lactic acid fermentation of milk through the action of Streptococcus thermophilus and lactobacillus bulgaricus (Adolfessonet al., 2004). It is more nutritious than many other fermented milk products because it contains a high level of milk solids in addition to nutrients developed during the fermentation process and its sensory attributes have a large effect on consumer acceptability (Sant - eve et al., 2008). Yoghurt whether produced from raw milk or fabricated milk, still has similar physical, chemical, sensory and microbiological properties. These properties are essential and must be preserved during storage. The chemical composition and microbiological quality of yoghurt has been reported by several workers Saint - eveet al., 2008; Yagygin and Kinc 1980; Dayisoylu, 1993; McGregor and white, 1986. Yoghurt is one of the oldest fermented milk products known. Fermentation of milk involves the action microorganisms, principally the lactic acid bacteria. These microorganisms sour the milk by converting the milk sugar lactose to lactic acid (Kagan, 1985). Yoghurt gels are built of dusters of aggregated case in particles formed as a result of gradual fermentation of lactose by lactic acid bacteria (Horine, 1999, 2003).

Nono is local uncontrolled fermented cow milk which forms a major part of the staple food in Northern Nigeria. They are produced mainly by the nomadic fulani. The fresh milk is directly obtained from a cow into properly washed semi-dried calabash and kept from a cow into properly washed semi-dried calabash and kept wide open in the sun for approximately two hours to facilitate isolation of the far layer. Some quantity of overnight fermented milk is added therefore to serve as starter culture and the inoculated fresh milk is left overnight at room temperature for fermentation to get our sour milk known as Kindirmo and the addition of large volume of water to the curdle sour milk which is then stirred with a T-shaped stick to a liquid of fine consistency.Giving rise to "Nono" the most commonly product often mixed with Nono is called "Fura" (a dumping made of millet) to make a preparation called "Fura da Nono". It is common experience that in northern part of Nigeria that direct consumption of locally processed raw milk in both cities and rural areas is much frequent 
and more popular than consumption of pasteurized milk because it is believed especially in rural areas that local processed raw milk and its by -products have nutritional advantages over the pasteurized one. Nono also called Nunu by some tribes in Nigeria contains good quantities of amino acids, calcium, phosphorus and vitamin A, C, E and the B complex (Nebedum and Obiakor, 2007).The aim is to assess the proximate parameters of the local (Fulani) yoghurt syrup to assess its nutritive value.

\section{Materials AND Methods}

\subsection{Sample Collection}

The fresh sample of Nono to be used for the study was obtained randomly around Bauchi State metropolis which includes: ATBU campus (1A \& 1B), Wunti Market, SabonKaura, and Gidan Mai, where most the Hausa/Fulani women hawk the product in plastics and calabashes. The 5 samples was collected randomly into a sterile bottle and taken immediately for analysis. It was labeled $(1 \mathrm{~A}, 1 \mathrm{~B}$, $1 \mathrm{C}, 1 \mathrm{D}$ and $1 \mathrm{E})$.

\subsection{Preparation of Samples}

\subsection{Preparation of Samples for Mineral Nutrient Analysis}

The Yoghurt samples were digested after adding $25 \mathrm{~mL}$ of tri-acid mixture $\left(\mathrm{HNO}, \mathrm{H}_{2} \mathrm{SO}_{4}\right.$ and $\mathrm{HClO}_{3}$ in $5: 1: 1$ ratio) at $80^{\circ} \mathrm{C}$ until a transparent solution was obtained. After cooling, the digested sample was filtered and the filtrate made to $100 \mathrm{~mL}$ mark with distilled water.

\subsection{Elemental Analysis for Mineral Nutrients}

Determination of Calcium and Magnesium ions were made by Atomic Absorption Spectrophotometer (combo HI 98130, Hanna USA).

\subsection{Proximate Analysis for Nutritive Composition}

The estimation of the various parameters namely moisture content, total ash content, crude protein, crude lipids, total carbohydrate value was carried out according to standard procedures. The recommended method of the AOAC was used.

\subsection{Determination of Moisture Content}

$2 \mathrm{~g}$ of the sample was weighed into a crucible, with the sample left to dry in the oven at $60^{\circ} \mathrm{C}$ for about 5hours. After which it was left to cool in a desiccator, before weighing. The loss in weight after drying is equal to the moisture content.

$$
\% \text { Moisture }=\frac{\text { Initial weight of Sample }- \text { Final weight of sample }}{\text { Initial weight of Sample }} \times 100
$$

Determination of Total Solid: the weight of the resident obtained from moisture content analysis was expressed as percentage total solids using the formula below:

$$
\text { Total solid }=\frac{\text { Weight of dish }+ \text { Dry Nono })-(\text { Weight of dish })}{\text { Weight of the sample }} \times 100
$$

\subsection{Determination of Ash Content}

$2 \mathrm{~g}$ of the sample was weighed into a crucible which was afterwards placed in a muffle furnace. The temperature of the furnace was held at $650^{\circ} \mathrm{C}$ for 6 hours and the weight of the ash was taken afterwards. The Ash content was calculated as;

$$
\% \text { Ash content }=\frac{\text { Weight of Ash }}{\text { Weight of Sample }} \times 100
$$

\subsection{Determination of Fat Content}

$10 \mathrm{~g}$ of the sample was weighed into a thimble and extracted with $\mathrm{n}-\mathrm{Hexane}$ using the soxhlet apparatus. After extraction the weight of the Hexane free extract is taken as the weight of the fat. The fat content is calculated as;

$$
\% \text { Fat content }=\frac{\text { Weight of Lipid }}{\text { Weight of Sample }} \times 100
$$




\subsection{Determination of Crude Protein Content}

The crude protein content was estimated using the macro Kjeldhal method (AOAC, 2005). $2 \mathrm{~g}$ of the sample was introduced into the digestion flask, followed by the addition of $6 \mathrm{~g}$ of Kjeldahl catalyst and $25 \mathrm{ml}$ of tetraoxosulphate (VI) acid. The mixture was put into a digestion block and heated in a fumes cupboard until it turns green. On cooling the mixture was filtered into a $100 \mathrm{~mL}$ volumetric flask and made to mark with distilled water.

$15 \mathrm{~mL}$ of the mixture was poured into the distillation apparatus along with $25 \mathrm{~mL}$ of $40 \% \mathrm{NaOH}$ solution. The content in the flask was heated to boil; the ammonia distillate was condensed and collected in a $10 \mathrm{~cm}^{3}$ Boric acid, using a Universal indicator. The digest in the indicator was titrated with $0.05 \mathrm{M} \mathrm{H}_{2} \mathrm{SO}_{4}$.

The nitrogen content was calculated using;

$$
\% \text { Nitrogen }=\frac{0.014 \times \text { Titre } \times \text { Volume of Digest } \times \text { Normality of Acid. }}{\text { Weight of Sample }(g) \times \text { Volume of Aliquot. }} \times 100
$$

The crude protein was calculated using;

$$
\% \text { Crude Protein }=\% \text { Nitrogen } \times 6.25
$$

\subsection{Determination of Carbohydrate}

The carbohydrate content was deducted using the formula below:

$$
\text { Carbohydrate }=100-(\% \text { Moisture }-\% \text { Protein }-\% \text { Lipid }-\% \text { Ash })
$$

\subsection{Determination of $\mathrm{Ph}$ Value}

The $\mathrm{pH}$ was determined using a Jenway $3105 \mathrm{pH}$ meter. The $\mathrm{pH}$ was determined at room temperature $\left(270^{\circ} \mathrm{C}\right)$ using a $\mathrm{pH}$ meter. The $\mathrm{pH}$ was calibrated with buffer standards of $\mathrm{pH} 4$ and $\mathrm{pH} 10.50 \mathrm{ml}$ of the nono was placed in a beaker, the probe of the $\mathrm{pH}$ meter was inserted and $\mathrm{pH}$ value was recorded. The probe was rinsed thoroughly with distilled water before used on sample.

\subsection{Determination of Acidity}

The titratable acidity was measured by titrating $15 \mathrm{ml}$ of the Nono with $0.1 \mathrm{M}$ sodium hydroxide until the substance reached a $\mathrm{pH}$ value 8.2 , corresponding to the end point of the phenolphthalein. The acid percentage of the substance was calibrated using the formula.

$$
\text { Titratable acidity }=\frac{\text { Titre value } \times M \times 90 \times 1000}{\text { Volume of sample } \times 1000}
$$

Where $\mathrm{M}=$ Molar Concentration of $\mathrm{NaOH}$

\subsection{Microbiological Analysis}

The microbial analysis of the sample was carried out by the method of (Ogbulie, et al, 1998) as described by Ehrim and Onyeneke (2013). Each sample was serially diluted in sterile distilled water to obtain the inoculums. An aliquot each dilution was cultured on Nutrient Agar (NA) for bacteria.

\subsection{Media Preparation for Total Plate Count}

$5 \mathrm{~g}$ of plate count agar was added to $250 \mathrm{~mL}$ of distilled water in a conical flask. It was heated to boiling and was then sterilized in an autoclave at $121^{\circ} \mathrm{C}$ for 15 minutes.

\subsection{Sample Preparation for Serial Dilution}

20 test tubes were prepared, sterilized and were labeled approximately $\left(10^{-1}=10^{-4}\right)$ according to the number of samples, and two were labeled as control for each sample. $9.0 \mathrm{~mL}$ each of distilled water was dispensed into the test tubes and were sterilized and then allowed to cool. $1 \mathrm{ml}$ of the sample was pipette into the first tube and was labeled $10^{-1}$ and $1 \mathrm{~mL}$ was transferred into the second test tube, from the second to the third until a dilution of $10^{-4}$ was obtained.

\section{RESUlT AND DISCUSSION}

The result obtained from the proximate analysis of locally prepared samples (nono) in Bauchi metropolis are presented in Table below. 
Table4.1. Proximate composition of different sample of Fulani yoghurt (Fulani) expressed as percentage dry weight

\begin{tabular}{|c|c|c|c|c|c|}
\hline Nono Sample & ATBU 1A & ATBU 1B & SABON KAURA & WUNTI & GIDAN MAI \\
\hline Moisture & $77.5 \pm 0.07$ & $80.9 \pm 0.1$ & $78.3 \pm 0.1$ & $74.5 \pm 0.1$ & $81.8 \pm 0.1$ \\
\hline Ash & $0.79 \pm 0.22$ & $2.25 \pm 0.05$ & $0.69 \pm 0.04$ & $0.70 \pm 0.05$ & $1.82 \pm 0.05$ \\
\hline Non fat solid & 7.5 & 4.2 & 13.5 & 6.0 & 1.0 \\
\hline Lipid & $15.0 \pm 0.05$ & $5 \pm 0.05$ & $8.0 \pm 0.00$ & $15.5+0.00$ & $11 \pm 0.1$ \\
\hline Carbohydrate & 6.19 & 11.31 & 12.49 & 8.76 & 5.81 \\
\hline Total solid & 22.5 & 19.10 & 21.5 & 23.6 & 18.2 \\
\hline Protein & 3.25 & 3.37 & 3.25 & 3.37 & 3.56 \\
\hline
\end{tabular}

Table4.2. Concentration of minerals content is $\mathrm{mg} / \mathrm{g}$

\begin{tabular}{|l|l|l|l|l|l|}
\hline Nono Sample & Atbu 1a & Atbu 1b & Wunti & Gida Mai & Sabo \\
\hline Calcium (mg/g) & 0.083 & 0.085 & 0.094 & 0.093 & 0.080 \\
\hline Magnesium (mg/g) & 1.64 & 1.66 & 1.64 & 1.62 & 1.62 \\
\hline
\end{tabular}

Table4.3. Concentration of Mineral content in $\mathrm{mg} / 100 \mathrm{~g}$

\begin{tabular}{|l|l|l|l|l|l|}
\hline Nono Sample & Atbu 1A & Atbu 1B & Wunti & Gidan Mai & Sabo Kaura \\
\hline Calcium mg/100g & 4.3 & 4.7 & 4.6 & 4.0 & 4.25 \\
\hline Magnesium mg/100g & 81.8 & 81.3 & 82.0 & 80.8 & 83.3 \\
\hline
\end{tabular}

Table4.4. Chemical analysis of the difference local yoghurt samples

\begin{tabular}{|l|l|l|}
\hline Samples & Parameter & pH \\
\hline & Titratable Acidity & 4.8 \\
\hline ATBU 1A & 0.56 & 4.6 \\
\hline ATBU 1B & 0.54 & 4.6 \\
\hline Wunti & 0.54 & 4.6 \\
\hline Gidan Mai & 0.55 & 4.7 \\
\hline Sabo Kaura & 0.55 & \\
\hline
\end{tabular}

Table4.5. Microbial analysis of the different yoghurt samples

\begin{tabular}{|l|l|}
\hline Sample source & Mean plate count $(\mathbf{c f u} / \mathbf{m l})$ \\
\hline SabonKaura & $7.1 \times 10^{5}$ \\
\hline Wunti & $3.0 \times 10^{5}$ \\
\hline ATBU 1A & $8.1 \times 10^{5}$ \\
\hline ATBU 1B & $5.0 \times 10^{5}$ \\
\hline Gidanmai & $6.8 \times 10^{5}$ \\
\hline
\end{tabular}

\subsection{Moisture Content}

From table I, there was significant differences in moisture content of samples of (Nono) obtained from different location. From the result, the moisture content of the sample ranged from $74.5 \%$ in Wunti to $81.8 \%$ in Gidan Mai. This value corresponded with the report by Ahmad, (1994) who stated that the maximum moisture content of yoghurt should be $84 \%$ as much water in yoghurt makes it less viscous thereby affecting texture and mouth feel. The very wide range of the moisture content of Gidan Mai from the other can be explained in terms of itsdilution in the course its preparation

\subsection{Ash Content}

From Table 1, the Ash Content of "Nono" local yoghurt obtained from Wuntiwas lowest at $0.70 \%$ and the highest at $2.25 \%$ for ATBU 1B. This value obtained from ATBU 1B was significantly higher than those of samples obtained from all the other places. The ash value is an index of minerals content, which is needed for bone development teeth formation and body functions (Tracho and Ministry, 1998). This therefore indicated that Gidan Mai sample with (1.82) and Atbu 1B (2.25) ash content indicated that their locally prepared yoghurt "Nono" are the better source of minerals among the samples.

\subsection{The Fat Content}

From Table I, the Fat content of the sample ranged from $5.80 \%$ for Wunti and to a higher value of $15.5 \%$ for ATBU 1A. There was a significant difference in the fat content of all the samples 
indicating the difference in their management of the animals in there feeding and. Fat play an important role in improving the consistency of yoghurt and also provide twice as much energy as same quantity of carbohydrates and protein (Ehirim and Onyeneke, 2013).

\subsection{The Protein Content}

From Table I, the protein content of the different samples for analyzed all fall within range of 3.5\% protein content of yoghurt reported by Early (1998).

\subsection{The Total Solids Content}

From Table I, the total solids content was lowest at 18.2 for Gidanmai, and highest at 23.5 for Wunti as compared to the yoghurt findings of Hofiet al., 1994 who stated that yoghurt should have a total solid of between 15\% and 16\% and Muhammedet al., (2005) who reported a higher total solid of $17.11 \%$. However, Weaver (1993) reported that low percentage of total solids in yoghurt can lead to malfunction of the starter culture.

\subsection{The Total Solid Non - Fat}

From Table 1, the total Solid non-fat of the different yoghurt samples ranged from $1.0 \%$ for Gidan Mai "Nono" to $13.5 \%$ for Sabo KauraNono. The result also shows a significantly difference in all the five samples.

\subsection{The Carbohydrate Content}

From Table I, the carbohydrate content of "Nono" ranged from $5.81 \%$ for Gidan Mai to $12.49 \%$ for Sabo Kaura. Samples of "Nono" from Sabo Kaura region, which had the lowest protein content was found to contain the highest value in carbohydrate. The values obtained from ATBU 1B is 11.31 and 12.49 for Sabo Kaura. The low carbohydrates value is attributed to the process of fermentation which converts carbohydrates basically lactose to lactic acid. This makes yoghurt an ideal good for lactose intolerance individuals (Ehirim and Ndimantang 2004).

\subsection{Concentration of Minerals Content is $\mathrm{mg} / \mathrm{g}$}

From Table II, Calcium content was observed to be in the range of $0.080-0.094(\mathrm{mg} / \mathrm{g})$. Lowest value $(0.080 \mathrm{mg} / \mathrm{g})$ was obtained from Sabo Kaura and highest value $(0.094 \mathrm{mg} / \mathrm{g})$ obtained from Wunti.

Magnesium (Mg): Magnesium content were between the range $(1.62-1.66(\mathrm{mg} / \mathrm{g}))$ with ATBU 1B having the highest content $(1.66 \mathrm{mg} / \mathrm{g})$ and those at Sabo Kaura with the least $(1.62 \mathrm{mg} / \mathrm{g})$. There was no significant different on all the five samples.

\subsection{Concentration of Mineral Content in $\mathbf{m g} / \mathbf{1 0 0 g}$}

From table III, it is observed that the samples are very rich in magnesium compared to calcium when compared with the mineral content in $100 \mathrm{~g}$ sample with the Recommended Dietary Allowance (RDA) in terms of their nutrient density as the samples contribution to the RDA was undertaken.

\subsection{Titratable Acidity}

From Table V, the total titratable acidity of the samples ranged from 0.54 for ATBU 1B and Wunti Local yoghurt to 0.56 for ATBU 1A. All the samples analyzed show similar titratable acidity values.

\subsection{1. pH}

The result of the $\mathrm{pH}$ of the different local yoghurt samples indicates that, there is no significant difference in the acidic level of ATBU 1B, Wunti and Gidan Mai local yoghurt. However ATBU 1A local yoghurt has the least acidic value.

\subsection{Result of Microbial Analysis of the Different Yoghurt Samples}

From Table VI, the result of the microbial analysis is presented in table 6 from the result, the total bacterial count of the local yoghurt sample ranged from $3.0 \times 105$ for Wuntito $8.1 \times 105 \mathrm{cfu} / \mathrm{g}$ for ATBU A. The original bacteria yoghurt are beneficial to human health.

\section{CONCLUSION}

This study showed that the five types of local made yoghurt "nono" that were analysed do not contain bacteria that would have posed a health risk to consumers. The local yoghurt is rich in ash content, an indication of presence of minerals and other nutrients in adequate quantities, yoghurt is an excellent 
source of vitamins, calcium, phosphorus, potassium and proteins so should be consumed by both children and adults. The significant different values obtained for the means of microbial groups in this study could be due to lack of standardized method of nono preparations or the health status of the milk producing animals or other environmental variables.

\section{REFERENCES}

[1] Adolfson, O., S.N., Meydani and R.M Russel 2004. Yoghurt and gut function. Am.Jclin.Nutri, 80: 245 256.

[2] Ahmad J (1994), quality characteristics of plain yoghurt made from standardized Bufallo milk M.Sc thesis university of AgricFalsalAbda.

[3] AOAC 1990: Official Methods of Analysis. Association of Anatical Chemist, Washington D.C, USA.

[4] AOAC (2005) "Official Methods of Analysis" Association of Official and Analytical Chemist, Washington D.C $\left(12^{\text {th }}\right.$ ed $)$.

[5] Dayisojiu KS (1993). A study of the physical, chemical, microbiological and flavor characteristics of yoghurt commercially produced and solid in van, Turkey, master thesis, YuzuncuVil University.

[6] Early R (1998).The technology of dairy products ( $2^{\text {nd }}$ Ed International Thomson publishers.

[7] Ehirim FN, Ndimantang, BE (2003). Physiochemical and organoleptic properties of Yoghurt manufactured with cow milk and goat milk natural and applied Sci 4 (4).

[8] Ehirim FN, Onyeneke EN (2013) physicochemical ed Organoleptic properties of Yoghurt, Manufactured with cow milk ed goat milk, Natural ed Applied Sci 4(4).

[9] Ehirim FN, Ndimantang BE (2004) production and Evaluation of Yoghurt from cow-soy milk Blends J. Agric and food Sci

[10] Hofi A.A, Dien H, Elishibing s. (1994). The chemical composition of market yoghurt.Eyptians J. diary Sci 6: $25-31$.

[11] Horine D.S (2003) Casein micelles as hard Spheres Limitation of the Model in acidified gel formation colloids Surf A. Physicocliem.Eng ASP. 213:255 - 263

[12] Horine D.S (1999) Formational structure of acidify milk gels Int. Dairy J. 9:261 - 268

[13] Kagam J. (1985) Yoghurt a rising star in the Dairy Industrt.Cult.Dairy Prod. J. 20(1): 24 - 29

[14] Muhammed B.F. Abubakar MM, Muir OnyaWonye O (2005) effect of culture concentration and inoculation temperature on physicochemical, microbiology and organoleptic properties of yoghurt Nig, food J. $23156-165$.

[15] Mc-GregorJu, white CH (1982) effect of sweeteners on the quality ed acceptability of Yoghurt J. Dairy sci 69:698- 703 .

[16] Nebedum J. O \& T. Obiakor 2007. The effects of different presentation methods on the quality of Nono. A locally fermented Nigerian Dairy Product Afr. J. Brotechnol. 6.454 - 458

[17] Saint Eve H, Levy C, Moigne Dem, DurutSochon (2008) Quali, changes in yoghurt during Storage in different packaging material.Food chemistry. Salman, Adil M.A Hamad I.M (2011). Enumeration and identification of Coliform bacteria from raw milk in Khartoum state, Sudan J. Cell, Anim Bio. s (7): 121 128.

[18] Trachoo N, Mistry V.V (1998). Application OD Ultra Filteral sweet butter milk and sweet butter milk powder in Yoghurt manufacture of non-fat and low fat yoghurt. J diary Sci 81: $\quad$ 774-788.

[19] Weaver JS (1993) Health benefits of yoghurt retrieved from www. leaflady.org/yoghurt/htm

[20] Yaggin H, Kilic M (1980). A study on properties of yoghurt produced started culure and carryover culture techniques. $7^{\text {th }}$ scientific congress, Agriculture and research group $6-10^{\text {th }}$ Oct Adana turkey.

Citation: M. Shibdawa, et.al, "Physiochemical Analysis of Local (Fulani) Yoghurt Syrup Sold in Bauchi Metropolis". International A., Journal of Advanced Research in Chemical Science (IJARCS), 5(4), pp. 17-22, DOI: http://dx.doi.org/10.20431/2349-0403.0504005

Copyright: () 2018 Authors. This is an open-access article distributed under the terms of the Creative Commons Attribution License, which permits unrestricted use, distribution, and reproduction in any medium, provided the original author and source are credited. 